07.2

\title{
Аномалии в фотовольтаических характеристиках многопереходных солнечных элементов при сверхвысоких концентрациях солнечного излучения
}

\author{
(C) М.А. Минтаиров, В.В. Евстропов, С.А. Минтаиров, М.З. Шварц, Н.А. Калюжный \\ Физико-технический институт им. А.Ф. Иоффре РАН, Санкт-Петербург, Россия \\ E-mail: mamint@mail.ioffe.ru
}

Поступило в Редакцию 10 июля 2019г.

В окончательной редакции 10 июля 2019г.

Принято к публикации 16 июля 2019г.

Исследована аномалия, возникающая в фотовольтаических характеристиках трехпереходных $\mathrm{GaInP} / \mathrm{GaAs} / \mathrm{Ge}$ и соответствующих двухпереходных $\mathrm{GaInP} / \mathrm{GaAs}$ солнечных элементов при сверхвысоких концентрациях (более 2000 солнц) падающего излучения. Проанализированы световые вольт-амперные характеристики при различных концентрациях падающего излучения и зависимость напряжения холостого хода от фотогенерированного тока. Показано, что причиной аномалии является встречно включенный между субэлементами GaInP и GaAs туннельный диод, поглощающий прошедшие сквозь слои GaInP фотоны и генерирующий встречную фотоэдс.

Ключевые слова: многопереходный солнечный элемент, концентрированное солнечное излучение, фотовольтаические характеристики, вольт-амперные характеристики, встречная электродвижущая сила, туннельный диод.

DOI: 10.21883/PJTF.2019.21.48472.17973

Соединительные части между субэлементами - необходимый компонент многопереходных солнечных элементов (СЭ). Для того чтобы эти межсоединения могли выполнять свою соединительную функцию, их конструкции имеют сложное строение, приводящее к противоречивым результатам. Один из таких результатов обнаружен в верхней соединительной части трехпереходного $\mathrm{C} Э \mathrm{GaInP} / \mathrm{GaAs} / \mathrm{Ge}$ между субэлементами GaInP и GaAs. Это аномальная форма характеристики $V_{o c}-J_{g}$ (напряжение холостого хода-фотогенерированный ток), построенной в полулогарифмическом масштабе (рис. 1). Наблюдается сублинейность при сверхвысоких концентрациях $(X \geqslant 2000$ солнц) падающего излучения вплоть до появления падающего участка [1-3]. Эта аномалия внешне похожа на эффект нагрева структуры падающим

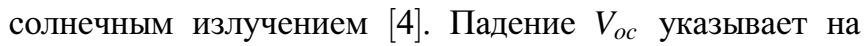
снижение эффективности, поэтому определение происхождения этой аномалии представляет собой практически значимую задачу. Аномалия наблюдалась также в поведении формы световой вольт-амперной характеристики (BAX): противоположная зависимость тока от концентрации падающего излучения на разных участках этой кривой (рис. 2). Эта аномалия не похожа на эффект нагрева. Настоящая работа посвящена доказательству возникновения фотовольтаического эффекта, противодействующего субэлементам, в туннельном гетеропереходе $p^{+}-n^{+}$.

Для доказательства были исследованы характеристики двухпереходного CЭ $\mathrm{GaInP} / \mathrm{GaAs}$, у которого конструкция соединительной части повторяет типичную конструкцию соответствующей части трехпереходного
CЭ GaInP/GaAs/Ge. Выбор именно этой соединительной части вызван тем, что в соответствующем туннельном диоде возможно поглощение света, предназначенного для субэлемента GaAs.

В качестве объекта исследования был выбран двухпереходный $\mathrm{C} \ni \mathrm{GaInP} / \mathrm{GaAs}$, содержащий в своей соединительной части туннельный гетеропереход $p^{+}-\mathrm{Al}_{0.4} \mathrm{Ga}_{0.6} \mathrm{As}-n^{+}-\mathrm{GaAs}$. Световые ВАХ были получены при облучении источником на основе импульсной ксеноновой лампы. Номинальная концентрация солнечного излучения определялась исходя из значения измеренного фотогенерированного тока $\left(J_{1 \text { Sun }}=14.3 \mathrm{~mA} / \mathrm{cm}^{2}\right.$ для спектра AM1.5D).

Для исследуемого прибора были получены BAX при различных концентрациях падающего излучения вплоть до сверхвысоких (более 2000 солнц). На рис. 1 приведена экспериментальная зависимость напряжения холостого хода от фотогенерированного тока, равного в данном случае току короткого замыкания. Эта зависимость обладает линейным (в полулогарифмическом масштабе) участком вплоть до 600 солнц. Этот участок аппроксимировался экспонентой с диодным коэффициентом $A=3$ и током насыщения (предэкспонентой) $J_{0}=6.5 \cdot 10^{-16} \mathrm{~A} / \mathrm{cm}^{2}$. Отметим, что для двухпереходного СЭ диодный коэффициент задается суммой двух диодных коэффициентов его субэлементов (обычно для одного субэлемента $A=1$ или 2) [5]. Результат аппроксимации приведен на рис. 1 (штриховая линия). Аппроксимация была использована для расчета зависимости $V_{o c}-J_{g}$, учитывающей нагрев СЭ падающим излучением (рис. 1, пунктирная линия). Для расчета 


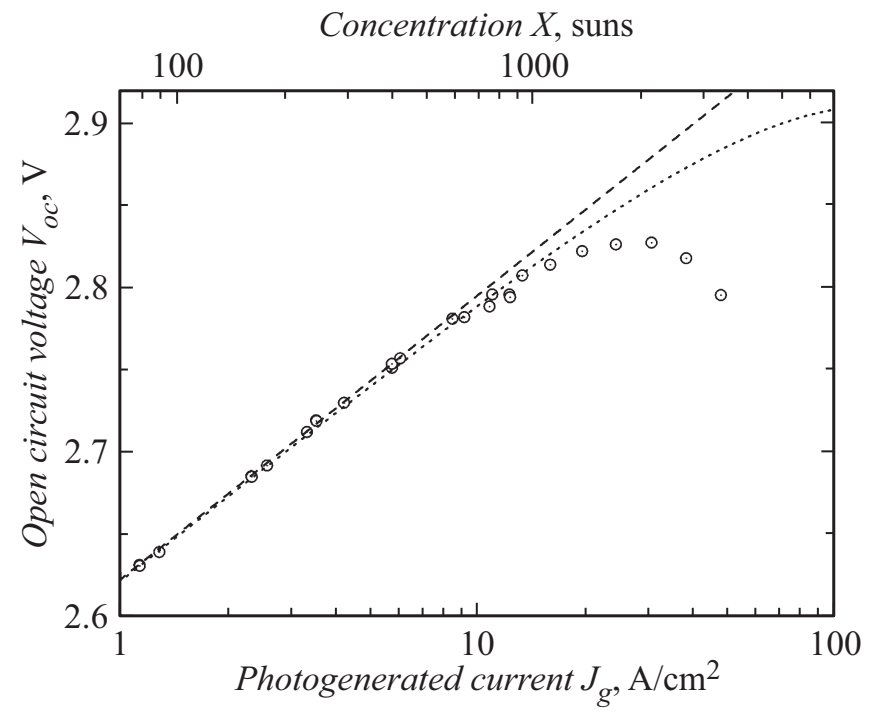

Рис. 1. Зависимость напряжения холостого хода от фотогенерированного тока. Символы - эксперимент, штриховая линия - расчетная изотермическая зависимость, пунктирная линия - расчетная зависимость, полученная из изотермической при учете влияния нагрева.

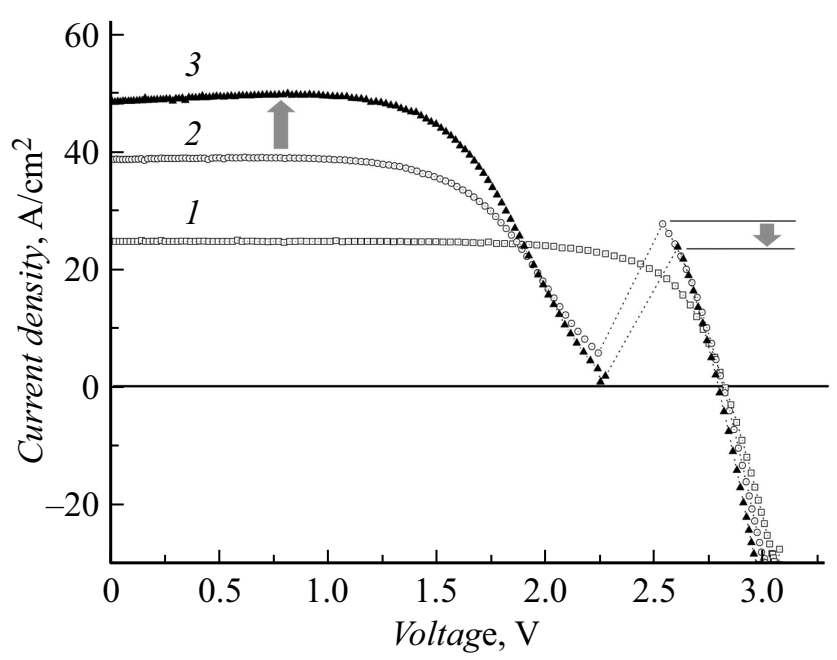

Рис. 2. Световые вольт-амперные характеристики при различных концентрациях падающего излучения. $1-1700$ солнц, $2-2700$ солнц, $3-3350$ солнц.

использовалась характеристика $\Delta V_{o c}-J_{g}$, приведенная на рис. $2, b$ в работе [6], где $\Delta V_{o c}$ - падение напряжения в результате нагрева. Эта характеристика показывает, насколько уменьшается из-за нагрева напряжение холостого хода трехпереходного солнечного элемента $\mathrm{GaInP} / \mathrm{GaAs} / \mathrm{Ge}$ при увеличении фотогенерированного тока. При использовании этой кривой для $\Delta V_{o c}$ был введен коэффициент 2/3, поскольку в данной работе исследовался двухпереходный элемент, в котором падение $V_{o c}$ составляет примерно $2 / 3$ от падения в трехпереходном СЭ (в предположении, что напряжение равномерно падает на всех субэлементах). В результате была получена расчетная зависимость $V_{o c}-J_{g}$, учитывающая как экспоненциальный рост $V_{o c}$, так и влияние перегрева прибора на характеристику (рис. 1, пунктирная линия). Видно, что экспериментальная кривая идет заметно ниже. Таким образом, существует другая причина (не нагрев) падения напряжения холостого хода. Было сделано предположение и подтверждено, что такой причиной являются поглощение фотонов и, следовательно, фотовольтаический эффект в туннельном диоде. Отметим, что для реализации токовой развязки в соединительных частях многопереходных СЭ используются встречно включенные туннельные диоды. Поглощение света в таких диодах вызывает встречную фотоэдс. Факт подобной фотогенерации был зафиксирован на ВАX (рис. 2). Показано, что ток короткого замыкания (равный фотогенерированному току солнечного элемента) увеличивается, а „горб“ на ВАХ туннельного диода идет вниз (стрелки на рис. 2). Это объясняется тем, что ВАХ субэлементов смещается вверх, тогда так ВАХ туннельного диода смещается вниз, что свидетельствует об их противодействующей (встречной) фотоактивности.

Таким образом, одна из возможных интерпретаций аномалии фотовольтаических характеристик трехпереходных CЭ GaInP/GaAs/Ge связана с фотовольтаическим источником, противодействующим субэлементам.

Анализ конструкции СЭ показал возможное расположение этого источника - туннельный диод между субэлементами GaInP и GaAs. Для полного выяснения причины аномалии был исследован двухпереходный СЭ $\mathrm{GaInP} / \mathrm{GaAs}$, воспроизводящий соответствующий участок трехпереходного СЭ.

Поведение световых ВАХ при изменении концентрации падающего излучения показало, что причиной аномалии действительно является встречно включенный туннельный диод, освещаемый фотонами, дошедшими до него сквозь субэлемент GaInP. Таким образом, доказано, что этот туннельный диод может работать как фотовольтаический источник, противодействующий субэлементам.

\section{Конфликт интересов}

Авторы заявляют, что у них нет конфликта интересов.

\section{Список литературы}

[1] Stevens M., Downs C., Emerson D., Adler J., Maclachlan S., Vandervelde T.E. // Proc. of 31st European Photovoltaic Solar Energy Conference and Exhibition (EU PVSEC 2015). Hamburg, 2015. P. 1474-1477.

[2] Geisz J.F., Duda A., France R.M., Friedman D.J., Garcia I., Olavarria W., Olson J.M., Steiner M.A., Ward J.S., Young M. // AIP Conf. Proc. 2012. V. 1477. P. 44-48. 
[3] Mintairov M.A., Evstropov V.V., Shvarts M.Z., Kozhukhovskaia S.A., Mintairov S.A., Kalyuzhnyy N.A. // AIP Conf. Proc. 2016. V. 1766. P. 050005.

[4] Reichmuth S.K., Helmers H., Garza C.E., Vahle D., de Boer M., Stevens L., Mundus M., Bett A.W., Siefer G. // Proc. of 32nd European Photovoltaic Solar Energy Conference and Exhibition (EU PVSEC 2016). Munich, 2014. P. 5-10.

[5] Wufler P. Physics of solar cell. Wiley-VCH Verlag, 2005. P. 126.

[6] Mintairov M.A., Evstropov V.V., Mintairov S.A., Shvarts M.Z., Kalyuzhnyy N.A. AIP Conf. Proc. 2018. V. 2012. P. 040007. 